\title{
Peran Kepemimpinan H. Ahmad Jayani dalam Meningkatkan Kinerja Staf Pengajar
}

\author{
Dadan Marathon $^{1 *}$, Dadang Kuswana ${ }^{2}$, Yuliani $^{3}$ \\ 13Jurusan Manajemen Dakwah, Fakultas Dakwah dan Komunikasi, UIN Sunan Gunung Djati, \\ Bandung \\ ${ }^{2}$ Jurusan Pengembangan Masyarakat Islam, Fakultas Dakwah dan Komunikasi, UIN Sunan \\ Gunung Djati, Bandung \\ *Email : dadanmarathon@gmail.com
}

\begin{abstract}
ABSTRAK
Penelitian ini bertujuan untuk mengetahui peran kepemimpinan H. Ahmad Jayani dalam meningkatkan kinerja staf pengajar. Peran pertama, peran pribadi yaitu peran sebagai figur head, leader, dan liasion. Kedua, peran sumber informasi yaitu peran sebagai monitor and desiminator, dan spoke person. Ketiga peran pembuat keputusan yaitu peran sebagai enterpreneur, distreubance bandler dan negotiator. Penelitian ini menggunakan pendekatan kualitatif dengan metode deskriptif. Hasil penelitian menunjukkan bahwa peran kepemimpian H. Ahmad Jayani dalam meningkatkan kinerja staf pengajar di pondok pesantren Ibnu Rusyd dilakukan dengan baik, peran interpersonal role, figur head dengan memberikan contoh, leader memberikan motivasi, liaison dengan menjaga hubungan baik. Peran informational role, monitor and dessiminator dengan menyaring dan menyampaikan informasi, spoke person dengan menjadi pembicara bagi pesantren. Peran decision making, enterpreneur mengidentifikasi ide baru, distrubance hendler terjun langsung mengatasi masalah, resorurce allocation keputusan dalam menempatkan sumber daya manusia, negosiator dengan bernegosiasi dengan pihak luar atau dengan staf pengajar.
\end{abstract}

Kata Kunci: Peran; Kepemimpinan; Kinerja; Staf.

\section{ABSTRACT}

This study aims to determine the leadership role of $H$. Ahmad Jayani in improving the performance of teaching staff. Through the first, a personal role that is the role as a figure head, leader, and liasion. Second, the role of the source of information is the role of monitor and desiminator, and spoke person. The three roles of decision makers are roles as entrepreneurs, distrubance handlers and negotiators. This research uses a qualitative approach with descriptive methods. The results showed that the leadership role of $H$. Ahmad Jayani in improving the performance of teaching staff at Ibnu Rusyd's Islamic boarding school bad always been done 
D. Marathon, D. Kuswana, Yuliani.

well, interpersonal roles, head figures by giving examples, leaders providing motivation, liaison by maintaining good relations. The role of informational role, monitor and testing by filtering and conveying information, speaking person by being a speaker for pesantren. The role of decision making, entrepreneurs identify new ideas, distribution hendler plunge directly to overcome the problem, resort allocation decisions in placing buman resources, negotiators by negotiating with outsiders or with teaching staff.

Keywords: Role; Leadership; Performance; Staff

\section{PENDAHULUAN}

Kehidupan manusia dalam kelompok baik besar maupun kecil, baik kelompok formal maupun non formal, yang dibentuk secara sengaja maupun tidak disana akan terdapat pemimpin (Badeni, 2014: 1). Manusia memiliki peran utama dalam suatu manajemen, demikian dengan suatu organisasi atau lembaga yang merupakan tempat berkumpul unsur manusia yang menjadi unsur penting dalam berjalannya suatu aktivitas organisasi. Peranan merupakan aspek dinamis kedudukan (status). Apabila seseorang melakukan hak dan kewajibannya sesuai dengan kedudukannya, dia menjalankan suatu peranan (Soekanto, 2012: 212).

Organisasi atau lembaga baik itu kepemerintahan maupun kemasyarakatan, tentunya diperlukan peranan dari seorang pemimpin yang berkompeten dalam memimpin suatu organisasi sehingga berjalan efektif dan efisien dalam pencapaian tujuan. Seorang pemimpin harus bisa merangkul serta mempengaruhi stafnya untuk mencapai tujuan organisasi yang telah ditetapkan. Koontz dan Donnel 1984 kepemimpinan yaitu sebagai pengaruh, seni atau proses mempengaruhi orang-orang sehingga mereka akan berusaha mencapai tujuan kelompok dengan kemampuan dan antusias (Hasibuan, 2001: 198).

Pelaksanaan kegiatan pada suatu organisasi seorang pemimpin selalu melimpahkan tugas kepada stafnya, ini bertujuan untuk memepermudah serta mempercepat proses penyelesaian kegiatan organisasi. Untuk menyelesaikan tugas tersebut para staf diharuskan mempunyai kecakapan, semangat kerja, disiplin dan tanggungjawab yang sangat akan mempengaruhi hasil kerja. Peran kepemimpinan seorang pemimpin dalam mengelola sumber daya manusia atau pun stafnya, keberhasilannya juga dipengaruhi oleh kinerja dari stafnya itu sendiri. Interaksi sosial antara pemimpin dengan stafnya dilandasi dengan aturan, ketaatan seorang staf terhadap kebijakan pemimpin dengan mengharap sebuah kerjasama dan keberhasilan.

Hal yang perlu diperhatikan dalam pelaksanaan pekerjaan atau tugas yaitu tercapainya kinerja yang baik, sesuai dengan standar kinerja yang telah ditetapkan oleh organisasi serta sesuai dengan visi dan misi organisasi. Banyak faktor yang mempengaruhi kinerja staf agar sesuai dengan yang diinginkan organisasi seperti peran pemimpin, budaya organisasi, motivasi kerja dan sebagainya. Berkaitan dengan hal tersebut, dalam penelitian ini akan membahas pada sisi peran 
kepemimpinan yang mungkin mempengaruhi dan meningkatkan kinerja staf.

Faktor yang diidentifikasikan mempengaruhi kinerja yaitu kepemimpinan. Seorang pemimpin dengan peran kepemimpinannya akan menentukan bagaimana strategi terhadap staf pengajar untuk melaksanakan tugas-tugas. Pemimpin yang berperan mengarahkan para staf untuk melaksanakan pekerjaan yang ditentukan. Kepemimpinan dalam konteks ini yang aka dikaji mengenai peran kepemimpinan (leadership role). Peningkatkan kinerja staf tentunya ada peran dari seorang pemimpin dalam kepemimpinannya. Dimana kepemimpinan adalah kemampuan seorang pemimpin untuk mengendalikan, memimpin, mempengaruhi pikiran, perasaan atau tingkah laku orang lain untuk mencapai tujuan yang telah ditentukan sebelumnya (Suradinata, 1997: 11). Peran kepemimpinan ini berpengaruh terhadap kinerja staf. Sebagaimana teori peran kepemimpinan yang dikemukakan oleh Henry Mintzberg (1973) ada tiga, yaitu: peran pribadi (interpersonal role) meliputi peran sebagai figur head, leader dan liaison; peran sumber informasi (informational role) meliputi peran sebagai monitor and desiminator dan spoke person; dan peran pembuat keputusan (decision making) meliputi peran sebagai enterpreneur, distrubance handler, resorurce allocation dan negosiator (Badeni, 2014: 6).

Peran kepemimpinan pada suatu organisasi, dimana setiap pemimpin memiliki peran masing-masing sesuai kompetensi dan wawasan yang dimiliki, semakin tinggi peran dari seorang pemimpin maka akan semakin memepengaruhi kelancaran kinerja staf untuk lebih semangat dalam melaksanakan tugas dan pencapaian tujuan organisasi yang telah ditetapkan. Melihat faktor tersebut mengenai peran kepemimpinan, peneliti ingin menganalisis bagaimana peran kepemimpinan tersebut terhadap kinerja staf. Untuk dapat meningkatkan kinerja staf maka dalam penelitian ini mengidentifikasikan perlunya peran kepemimpinan yang sesuai, dengan meningkatkan kinerja staf pada objek penelitian.

Pondok pesantren juga membutuhkan suatu peran dari seorang pemimpin. Peran kepemimpinan seorang pemimpin dalam mengelola sumber daya manusia keberhasilannya dipengaruhi oleh tingkat kinerja staf. Interaksi sosial antara pemimpin pesantren dengan staf pengajar dilandasi dengan aturan, ketaatan sorang pengajar terhadap kebijakan pemimpin dengan mengharap sebuah kerjasama dan keberhasilan. Kepemimpinan penggerak segala sumber daya manusia dan sumber daya lain yang ada pada dalam organisasi (Arifin, 2004: 23).

Pondok pesantren Ibnu Rusyd memerlukan suatu peran kepemimpinan dari H. Ahmad Jayani selaku pendiri dan pimpinan pondok pesantren sampai sekarang. Berdasarkan observasi, ada permasalahan yang timbul dari kinerja para staf pengajarnya, yaitu ada kekurangan dalam melaksanakan tugas dan kewajibannya dalam mengajar seperti seharusnya. Mulai dari keterlambatan saat jam mengajar dan tidak adanya koordinasi kepada pimpinan saat ada keperluan 
D. Marathon, D. Kuswana, Yuliani.

sehingga kelas mengajar pun jadi kosong tidak ada pengganti. Permasalahan ini terjadi karena pada setiap manusia tidak ada kesempurnaan, begitupun dengan staf pengajar di pondok pesantren Ibnu Rusyd ini yang mempunyai karakter dan kepribadian masing-masing. Oleh karena itu peran H. Ahmad Jayani akan sangat berpengaruh dalam mengatasi permasalahan tersebut untuk meningkatkan kinerja staf pengajar agar lebih baik.

Melihat permasalahan di atas, maka peneliti merasa perlu melakukan penelitian ini agar bisa mengatasi suatu permasalahan yang ada di pondok pesantren untuk terciptanya suasana kerja yang kondusif dan lebih baik untuk kedepannya. Dan tema yang diambil oleh penulis dalam penelitian ini adalah "Peran Kepemimpinan H. Ahmad Jayani dalam Meningkatkan Kinerja Staf Pengajar" di Pondok Pesantren Ibnu Rusyd Jl. Pondok Sadang No. 86 Cinunuk, Bandung.

Banyak penelitian yang telah dilakukan oleh orang lain berkaitan dengan tema tersebut, diantaranya: Pertama, Suhartini (2015) dengan judul Peranan Pemimpin Dalam Meningkatkan Kualitas Sumber Daya Manusia. Penelitian ini menjelaskan tentang pengoptimalan sumber daya yang ada, peningkatan pengetahuan dan keterampilan pengurus. Kedua, Fardi (2014) dengan judul Peran Kepemimpinan Ketua DKM Dalam Mengatasi Masalah Kinerja Staf. Penelitian ini menjelaskan tentang peran kepemimpinan beliau dalam memantau serta mengayomi seluruh aktivitas yang dilakukan oleh staf pengurus, memimpin rapat mengenai aktivitas kinerja staf pengurus, serta mengevaluasi seluruh aktivitas hasil kerja para staf pengurus. Ketiga, Wahyudi (2018) dengan judul Peran Pemimpin dalam Meningkatkan Kinerja Pegawai. Penelitian tersebut membahas kebijakan pemimpin BAZNAS Karawang yang menjadi pedoman atau acuan kerja para pegawai, implementasi kepemimpinan BAZNAS Karawang berfokus pada peningkatan kinerja pegawai dan evaluasi kepemimpinan yang terbagi menjadi 2 waktu yaitu jangka pendek (mingguan) dan jangka panjang (3 bulanan), mengevaluasi jalannya kepemimpinan dan juga mempersiapkan aktivitas yang akan datang.

Perbedaan penelitian ini dengan yang sebelumnya yaitu: Pertama, dengan skripsi Titin Suhartini, skripsi ini menjelaskan tentang peran pemimpin di PERMATA-KU untuk meningkatkan kualitas SDM, sedangkan penelitian saat ini untuk mengetahui peran pemimpin pondok pesantren Ibnu Rusyd untuk meningkatkan kinerja staf pengajar. Kedua, skripsi Abdul Fardi, skripsi ini menjelaskan tentang peran kepemimpinan ketua DKM dalam mengatasi masalah kinerja staf, sedangkan penelitian saat ini untuk mengetahui peran pemimpin pondok pesantren Ibnu Rusyd untuk meningkatkan kinerja staf pengajar. Ketiga, skripsi Eka Wahyudi, skripsi ini menjelaskan tentang peran pemimpin dalam meningkatkan kinerja pegawai di BAZNAS Karawang, sedangkan penelitian saat ini untuk mengetahui peran pemimpin pondok pesantren Ibnu Rusyd untuk 
meningkatkan kinerja staf pengajar.

Lokasi penelitian atau alamat pondok pesantren Ibnu Rusyd yaitu Jl. Pondok Sadang No. 86 Cinunuk, Bandung dengan pertanyaan penelitian: pertama, Bagaimana peran pribadi H. Ahmad Jayani dalam meningkatkan kinerja staf pengajar; kedua, Bagaimana peran sumber informasi H. Ahmad Jayani dalam meningkatkan kinerja staf pengajar; ketiga, Bagaimana peran pembuatan keputusan H. Ahmad Jayani dalam meningkatkan kinerja staf pengajar; dan untuk metode yang digunakan adalah metode deskriptif, dengan pendekatan kualitatif.

\section{LANDASAN TEORITIS}

Penelitian ini, penulis mengemukakan pengertian dengan teori Peran, Kepemimpinan, Kinerja, Staf dan Pesantren. Setiap penelitian tentunya memiliki teori yang akan menjadi bahan acuan untuk kemudian dibandingkan dengan situasi dan kondisi suatu objek penelitian. Adapun teori yang menjadi acuan pada penelitian ini yaitu teori yang dikemukakan oleh Henry Mintzberg 1973, pertama peran peibadi (Interpersonal role) sebagai figur head, leader dan liaison, kedua peran sumber informasi (Informational role) sebagai monitor and desseminator, spokesperson, ketiga peran pengambilan keputusan (Decision making) sebagai enterpreneur, disturbance handler, resource allocator dan negotiator (Badeni, 2014: 6). Sehingga peneliti dapat merumuskan pertanyaan penelitian serta membandingkan dengan objek penelitian.

Pertama, pengertian peran adalah perilaku yang diharapkan dari seseorang yang mempunyai suatu status. Setiap orang mungkin mempunyai sejumlah status dan diharapkan mengisi peran yang sesuai dengan status tersebut (Horton dan Hunt, 1999: 118). Peran adalah serangkaian perilaku yang diharapkan pada seseorang sesuai dengan posisi sosial yang diberikan baik secara formal maupun secarara informal. Peran didasarkan pada preskripsi (ketentuan) dan harapan peran yang menerangkan apa yang individu-individu harus lakukan dalam suatu situasi tertentu agar dapat memenuhi harapan-harapan mereka sendiri atau harapan orang lain menyangkut peran-peran tersebut (Friedman, 1998: 286). Dengan demikian sesuai dengan pengertian peran diatas sehingga dapat penulis simpulkan bahwa peran merupakan suatu tindakan yang diharapkan timbul dari seseorang sesuai dengan posisi atau jabatan yang didudukinya, baik dalam organisasi kepemerintahan atau kemasyarakatan.

Kedua, Kepemimpinan dalam bahasa Inggris disebut Leadership dan dalam bahasa arab disebut Zi'amah atau Imamah. Secara terminologi yang dikemukakan oleh Marifield dan Hamzah, kepemimpinan adalah menyangkut dalam menstimulasi, memobilisasi, mengarahkan, mengkoordinasi motif-motif dan kesetiaan orang-orang yang terlibat dalam usaha bersama (Yaqub, 1984: 125). Stephen P Robbins (2001) mengatakan: leadership as the ability to influence a group 
D. Marathon, D. Kuswana, Yuliani.

toward the achievement of goals artinya kepemimpinan dapat didefinisikan sebagai kemampuan seseorang untuk mempengaruhi suatu kelompok kearah tercapainya tujuan (Badeni, 2014:2). Kepemimpinan merupakan bagian dari fungsi-fungsi manajemen yang menduduki posisi strategis dalam sistem dan hirarki kerja dan tanggung jawab pada sebuah organisasi (Baidan dan Aziz, 2014: 126). Dengan demikian dapat disimpulkan bahwa pemimpin merupakan inti, sumber daya pokok serta menjadi titik sentral dari semua aktivitas yang terjadi dalam suatu organisasi untuk kemudian mengarahkan bawahan dalam penycapaian tujuan.

Koontz dan Donnel 1984 dalam Manajemen Dasar, Pengertian dan Masalah kepemimpinan yaitu sebagai pengaruh, seni atau proses mempengaruhi orang-orang sehingga mereka akan berusaha mencapai tujuan kelompok dengan kemampuan dan antusias (Hasibuan, 2001:198). George R. Terry 1960 kepemimpinan adalah kegiatan mempengaruhi orang-orang untuk berusaha mencapai tujuan bersama (Moeheriono, 2012:382). Malayu S.P Hasibuan menyatakan bahwa pemimpin adalah seseorang dengan wewenang kepemimpinannya mengarahkan bawahannya untuk mengerjakan sebagian dari pekerjaanya dalam mencapai tujuan (Hasibuan, 2006:43). Mengacu pada pengertian tersebut dapat dipahami bahwa pemimpin merupakan seorang pemimpin dengan wewenang kepemimpinannya untuk menggerakan dan mengarahkan semua bawahannya untuk mengerjakan segala aktivitas-aktivitas yang ada didalam organisasi sebagai upaya pencapaian suatu tujuan organisasi.

Ketiga, kinerja. Menurut Marihot Tua Efendi merupakan hasil kerja yang dihasilkan oleh pegawai atau perilaku nyata yang ditampilkan sesuai peranannya dalam organisasi. Kinerja juga berarti hasil yang dicapai seseorang baik kualitas maupun kuantitas sesuai dengan tanggungjawab yang diberikan kepadanya (Anoki, 2010: 29). Menurut Sulastri (2010: 168) dalam bukunya Sumber Daya Manusia Strategik istilah kinerja ini dipandangkan dari istilah "performance" dalam bahasa Inggris, yang berarti perbuatan, tindakan, penampilan, dan lainnya. Namun dalam ilmu manajemen, istilah kinerja ini selalu mendapat perluasan pengertian yang dikatikan terutama dengan pekerjaan dan kualitas atau tingkatan upaya yang dilakukan untuk mencapai tujuan tertentu, baik dalam sebuah organisasi atau pun perusahaan. Kinerja merupakan salah satu elemen penting yang harus terdapat dalam sebuah perusahaan dengan tingkat yang ditetapkan sebagai acuan.

Keempat, Staf. Menurut Henry Payol Staf adalah sebagai suatu penambahan kekuatan atau perbesaran kepribadian seseorang tenaga kerja eksekutif yang memberikan kekuatan, pengetahuan dan waktu yang tidak ada padanya (Mariho, 2001: 87). Adapun tugasnya, menurut Moony dan Reily bahwa fungsi staf dalam organisasi berarti pengabdian yang berupa pemberi pendapat atau nasihat, yang dapat dibedakan dari fungsi kekuasaan atau komando. Pengabdian ini mempunyai tiga taraf yang timbul dalam hubungan yang terjalin jelas. Taraf-taraf 
itu adalah taraf-taraf memberikan keterangan, memberikan pendapat dan mengawasi. Taraf memberikan keterangan yaitu berhubungan dengan hal-hal yang harus ketahui oleh yang berkuasa dalam merencanakan keputusankeputusan, taraf memberi pendapat dengan nasihat sebenarnya didasarkan atas keterangan itu, dan terhadap semua detail pelaksana. Melalui taraf terakhir itu sifat pemberian keterangan dan pemberian pendapat menjadi operatif dalam seluruh organisasi (Marihot, 2001: 88).

Sesuai dengan tugas-tugas staf seperti dikemukakan diatas, jelas bahwa staf tidak sama kedudukannya dengan seorang manajer. Ia hanyalah sebagai pembantu dari pemimpin dan tidak boleh mengeluarkan perintah kepada petugas-petugas ini. Mengenai hal ini, dengan tegas Beishline berkata sebagai berikut: ...salah satu tujuan organisasi staf adalah memungkinkan spesialisasi dalam manajemen tetapi anggota-anggota staf tidak boleh memberi perintah langsung kepada anggota-anggota organisasi kecuali kepada anggota-anggota bagian staf mereka sendiri, oleh karena mereka tidak memiliki kekuasaan memberi komando (Marihot, 2001: 88-89).

Dari uraian di atas, penulis simpulkan bahwa staf merupakan sekelompok orang yang berpotensi membantu, melaksanakan dan menyelesaikan tugas yang diamanahkan dari seorang pemimpin. Dengan demikian staf membantu, mengerjakan segala bentuk tugas yang harus diselesaikan pada sebuah organisasi.

Kelima, Pesantren. Pesantren beasal dari akar kata cantrik yang merupakan kata benda konkret, kemudian berkembang menjadi kata abstrak yang diimbuhi awalan "pe" dan akhiran "an" pergeseran tertentu kata cantrik berubah menjadi santri dan an berubah menjadi kata en sehingga lahirlah kata Pesantren. Sedangkan Pondok merupakan penyesuaian ucapan kata funduk dalam bahasa arab yang berati tempat menginap (Faisal, 1995: 194). Secara terminologis, pesantren didefinisikan sebagai lembaga pendidikan tradisional Islam untuk mempelajari, memahami, mendalami, menghayati, dan mengamalkan ajaran Islam dengan menekankan pentingnya moral keagamaan sebagai pedoman perilaku sehari-hari (Damopoli, 2011:58).

Menurut Dawam Raharjo, pondok pesantren merupakan tempat dimana anak-anak muda dan dewasa belajar secara lebih mendalam dan lebih lanjut agama Islam yang diajarkan secara sistematis, langsung dari dalam bahasa Arab berdasarkan pembacaan kitab-kitab klasik karangan ulama-ulama besar (Raharjo, 1995: 2). Dari pengertian di atas, dapat diambil kesimpulan bahwa pondok pesantren adalah gabungan antara pondok pesantren yang memberikan pendidikan dan pengajaran agama Islam yang disediakan pondokan atau tempat tinggal oleh kyai. Sebuah pondok pesantren pada dasarnya adalah asrama Isalam tradisional dimana para guru lebih dikenal dengan sebutan kyai. 
D. Marathon, D. Kuswana, Yuliani.

\section{HASIL DAN PEMBAHASAN}

Berdasarkan hasil wawancara dengan $\mathrm{H}$. Ahmad Jayani dan staf pengajar di pondok pesantren Ibnu Rusyd Cinunuk. Nama lengkap beliau adalah Drs. H. Ahmad Jayani, M. Ag. Beliau lahir di Pandeglang, 10 April 1953. Tempat tinggal beliau sekarang di Jl. Pondok Sadang No. 87 RT. 03/XI Desa Cinunuk Kecamatan Cileunyi Kabupaten Bandung. Sejarah berdirinya pondok pesantren Ibnu Rusyd ini didirikan sekitar tahun 1996 oleh tokoh pendirinya yaitu H. Ahmad Jayani. Berdirinya pondok pesantren Ibnu Rusyd ini dikarenakan beliau ingin mengembangkan dakwah. Pertama beliau dakwah yaitu didalam sebuah mushola kalau sekarang masjid Al-Hidayah, disinilah awal beliau menyampaikan ajaran-ajaran Islam. Sehingga terpikirkan oleh beliau untuk mendirikan sebuah pondok pesantren. Upaya mendirikan pondok pesantren saat itu beliau mengajak masyarakat atau tokoh-tokoh sekitar namun tidak ada antusias, dikarenakan kondisi masyarakat saat itu belum mengingat seberapa pentingnya pendidikan di pondok pesantren.

Mengingat belum tersedianya lahan tempat, saat itu juga diadakan upaya pencarian lahan sekitaran antara Ujung Berung sampai Cileunyi namun tidak mendapatkan hasil, mencari ke daerah Cipadati juga tidak menuai hasil. Meskipun tidak ada dorongan dari masyarakat beliau tetap ingin mendirikan pondok pesantren, ban yak teman sejawat beliau saat masih kuliah memberikan dorongan untuk pendirian pondok pesantren ini dengan memberikan sejumlah dana. Dan untuk lahan tempat beliau memutuskan membangun di tanah beliau sendiri yang berlokasi di jalan pondok sadang No. 86 tepat di pinggir rumah beliau dengan luas tanah sekitar $800 \mathrm{~m}^{2}$. Dikarenakan lahan sudah tersedia bantuan dana dari teman sejawat ada, maka kemudian beliau menguruskan pembangunan pesantren tersebut dan berdirilah pondok pesantren Ibnu Rusyd. Ahirnya pondok pesantren Ibnu Rusyd didirikan di lahan milik beliau sendiri seluas $800 \mathrm{~m}^{2}$ tepatnya disamping rumah beliau sebelah barat (Hasil wawancara dengan H. Ahmad Jayani pada tanggal 15 Juli 2019).

Visi pondok pesantren Ibnu Rusyd yaitu Menjadikan pondok pesantren yang berkualitas dalam rangka pembinaan generasi yang unggul yang dapat diaktualisasikan dalam bentuk IMAN, ILMU dan AMAL. Sedangkan misinya yaitu: (1) Menghasilkan lulusan (alumni) yang berkualitas dari segi dzikir, pikir dan karir. (2) Melayani dan melaksanakan apa yang menjadi harapan masyarakat untuk menciptakan generasi Islami yang terhindar dari sifat tak terpuji. (3) Mewujudkan generasi muda yang siap pakai dimana dan kapan saja mereka berada (Diambil dari kumpulan arsip dan dokumen di Pondok Pesantren Ibnu Rusyd Cinunuk, pada tanggal 15 Juli 2019). 


\section{Peran Kepemimpin H. Ahmad Jayani dalam Interpersonal Role (Peran Pribadi)}

Peranan ini dimana seorang pemimpin melakukan peran pribadinya, adapun bagian dari peran pribadi ada tiga yaitu pertama pemimpin sebagai lambang/simbolis atau figur head, kedua pemimpin sebagai leader dan ketiga pemimpin sebagai penghubung atau liaison sesuai dengan teori yang dikemukakan oleh Henry Mintzber (1973), peranan seorang pemimpin sebagai lambang/simbol atau figur head ini sangat diperlukan untuk menjalankan sejumlah kegiatan rutin yang bersifat legal dan social. Selain itu dalam peranan ini juga seorang pemimpin harus bisa menjadi contoh baik atau pun memberikan contoh baik kapada bawahannya. Dengan demikian bawahannya juga akan menirukan kebiasaan baik dalam kinerjanya sesuai dengan yang telah dicontohkan oleh pemimpinnya (Badeni, 2014: 6).

Dalam peran kepemimpinannya secara interpersonal dengan melakukan hubungan dengan para staff yayasan yang dipimpinnya semisal melakukan fungsi pokok diantaranya memimpin, memotivasi, mengembangkan dan mengendalikan semua yang berada dalam naungan yayasan. Adapun secara informational merotasi informasi yangdiminta oleh manajer ini biasanya berupa laporan pelaksanaan program serta masukan dari para staff baik mengenai analisis dan laporan perkembangan sumber yang menurutnya baik bagi kemajuan yayasan yang dipimpinnya (Prayogi : 2016).

Syarat menjadi pemimpin yaitu: (1) Dewasa, karena orang yang tidak dewasa tidak mungkin dapat memimpin dan anak kecil (orang yang belum dewasa) tidak dapat dimintai pertanggungjawaban atas perbuatannya. (2) Adil, memiliki akhlak mulia, bahasa yang digunakannya bahasa yang benar, dapat dipercaya ketika suka dan duka, terjaga dari perbuatan yang diharamkan, dan terjaga kehormatannya dari urusan agama dan dunia. (3) Memiliki ilmu yang cukup untuk menyelesaikan peristiwa yang terjadi secara tak terduga dalam bidang politik, ekonomi, dan keluarga. (4) Kebijakan dalam menentukan kebijakan politik, perang dan administrasi. (5) Kuat keperibadiannya (sehingga berani, teguh hati, cakap dalam mempertahankan negara, melawan musuh, menegakkan hudud, dan menolong orang yang dianiaya). (6) Sepurna fisik (dapat mendengar, melihat, dan bicara), dan (7) Berasal dari golongan Quraisy (Sa'diyah: 2015).

Peran seorang pemimpin sebagai pemimpin atau leader, dalam peranan ini seorang pemimpin bertanggung jawab untuk memotivasi dan mengarahkan bawahan. Motivasi merupakan salah satu aspek yang sangat penting dalam menentukan perilaku seseorang, termasuk perilaku kerja. Agar seseorang mampu memotivasi seseorang, ia perlu mamahami bagaimana proses motivasi itu terbentuk. Motovasi merupakan dorongan internal, karena kebutuhan muncul dan menggerakan perilaku semata-mata karena tuntutan fisik dan psikologis yang 
D. Marathon, D. Kuswana, Yuliani.

muncul melalui mekanisme sistem biologis manusia. Teori motivasi kebutuhan yang dikemukakan oleh Abraham Maslow, bahwa manusia dimotivasi untuk memuaskan sejumlah kebutuhan yang melekat pada diri setiap manusia yang cenderung bersifat bawaan. Ia menghepotesakan bahwa didalam manusia itu ada lima jenjang kebutuhan yang terbentuk dalam suatu hierarki pemenuhan kebutuhan. Kebutuhan tersebut adalah kebutuhan fisik, keamanan, sosial, penghargaan, dan aktualisasi diri. Tingkat paling awal manusia akan berusaha memenuhi kebutuhan tingkat pertama, baru kemudian berusaha memenuhi kebutuhan tingkat kedua, dan seterusnya. Pemenuhan semua kebutuhan inilah yang menyebabkan seseorang bermotivasi (Badeni, 2014: 76-79).

Fungsi pengawasan juga tentu perlu dilakukan oleh seorang pemimpin terhadap kinerja bawahannya. Fungsi pengawasan ini dilaksanakan oleh pimpinan pondok pesantren ketika telah melaksanakan kegiatan, maka pimpinan dan seluruh staf selalu mengadakan evaluasi terhadap jalannya kegiatan yang telah dilakukan, apakah lebih baik dari sebelumnya atau malah sebaliknya, biasanya dalam bentuk rapat terbatas. Yaitu dengan memberikan laporan kepada setiap pengurus yang telah mendapatkan tugas. Hal ini dilakukan tidak hanya setiap telah melakukan kegiatan melainkan dilaksanakan pada setiap program (Alkhairy, 2017).

Demikian juga dengan staf pengajar di pondok pesantren Ibnu Rusyd ini kinerja tentunya didorong oleh adanya dorongan motivasi dari dalam dirinya untuk memenuhi segala kebutuhan dan keinginannya. Selain itu, karena ada pengawasan yang dilakukan oleh seorang pemimpin terhadap kinerja bawahannya. Pengawasan ini senantiasa akan melihat pergerakan atau aktivitas kerja dari bawahannya. Sehingga kinerja bawahan akan terkontrol dengan adanya fungsi pengawasan tersebut.

Peran pribadi seorang pemimpin sebagai penghubung atau liaison, dalam peranan ini seorang pemimpin harus bisa memelihara jaringan kontak atau hubungan komunikasi dengan pihak luar terutama yang memberikan dukungan dan informasi untuk mengembangkan kegiatan pesantren. Dengan kata lain dengan adanya hubungan komunikasi yang terjalin akan lebih mudah untuk mendapatkan informasi-informasi yang mendukung kegiatan, selain itu dengan adanya informasi yang didapat pesantren dapat menyesuaikan dengan sesuai dengan perkembangan zaman sehingga tidak tertinggal. Peranan penhubung atau memelihara jaringan kontak ini sangatlah penting dilakukan oleh seorang pemimpin, karena jika seorang pemimpin tidak menjalankan peranan ini sehingga pesantren tidak mendapatkan perkembangan aktivitas kegiatan karena tidak adanya informasi pendukung yang masuk dan bisa dijadikan acuan untuk mengembangkan kegiatan. Oleh karena itu, seorang pemimpin harus bisa memelihara jaringan kontak tersebut, karena dengan adanya relasi dengan satu pihak luar bahkan semakin banyak akan semakin baik tentunya akan 
menimbulkan informasi penting dan mendukung kegiatan yang sangat banyak juga untuk menjadi bahan pertimbangan dalam pengembangan kegiatan pesantren.

Peran sebagai figurhead, dimana dalam peran ini seorang pemimpin diperlukan untuk menjalankan sejumlah kegiatan rutin yang bersifat legal dan sosial. Seorang pemimpin juga harus bisa menjadi panutan bagi bawahannya, sesuai dengan kutipan dari jurnal ilmu dakwah: seorang da'i menjadi panutan para mad'u-nya, oleh karena itu penting sekali seorang da'i memberikan contoh dalam bertutur maupun bertindak dengan baik yang nantinya dijadikan figur seorang pemimpin (panutan dalam agama) yang baik. Ketika sudah mampu mengambil tempat dihati para mad'u, maka akan lebih mudah seorang da'i mengajak ke arah kebaikan (Farihah \& Ismanto: 2018).

Berdasarkan hasil wawancara dengan Zulfi Zakiah, ia mengatakan: beliau selalu memberi contoh yang baik, seperti setiap mau datang magrib selalu bergegas ke masjid untuk persiapan shalat, demikian juga saat menjelang waktu isya, beliau selalu mengajak untuk segera membereskan kegiatan pengajian dan segera persiapan untuk sholat isya berjamaah. Menurut Indah Larasati mengatakan: dari hal kecil juga beliau selalu memberi contoh, seperti tadi sebelum magrib beliau terlihat membawa sampah kecil dilapangan dan membuangnya ke tempat sampah. Ini merupakan suatu kebiasaan yang patut kita tiru (Wawancara dengan staf pengajar, pada tanggal 16 Juli 2019).

Dari hasil wawancara diatas, penulis menyimpulkan bahwa peran kepemimpinan H. Ahmad Jayani sebagai figurhead untuk memberikan contoh baik terhadap staf pengajar lebih bersifat sosial. Sehingga para staf pengajar dengan sendirinya akan mengikuti kebiasaan baik sorang pemimpin tersebut dengan kata lain staf pengajar juga secara otomatis memberi contoh baik terhadap murid-muridnya dan kinerja staf pengajar juga akan meningkat terlebih yang bersifat sosial dan memberi contoh baik kepada muridnya.

Peran sebagai leader, dimana peran seorang pemimpin harus bertanggung jawab untuk memotivasi dan mengarahkan bawahan. Motivasi merupakan pengejawantahan lain dari komunikasi organisasi sebab memiliki tujuan akhir yang sama, yakni munculnya tindakan positif untuk kelangsungan organisasi dalam mencapai tujuan. Purwanto (1998: 72) menyatakan bahwa aspek-aspek dalam motivasi adalah sebagai berikut: (a). Menggerakkan. Berarti menimbulkan kekuatan pada individu dalam memimpin seseorang untuk bertindak dengan cara tertentu. Maksud dari menggerakkan di sini yaitu memberikan materi dan ajaran mengenai motivasi berpuasa berupa tujuan berpuasa, kewajiban berpuasa dan hikmah berpuasa. (b). Mengarahkan. Motivasi menyediakan suatu orientasi tujuan tertentu. Dalam hal ini tingkah laku individu diarahkan terhadap sesuatu. Maksud dari mengarahkan di sini yaitu individu diberikan motivasi agar dapat menjalankan puasa seperti yang telah diperintahkan dalam agamanya. c. 
D. Marathon, D. Kuswana, Yuliani.

Menopang. Untuk menjaga tingkah laku, peran lingkungan sekitar harus dapat menguatkan intensitas dan arah, dorongan-dorongan, kekuatan individu. Maksud dari menopang di sini yaitu dalam proses pemberian motivasi ini lingkungan turut serta aktif dalam proses penyampaiannya (Marlina: 2014).

Berdasarkan hasil wawancara dengan Hildan Misbahul Munir mengatakan: dimana saat itu terjadi pembicaraan antara dia dengan H. Ahmad Jayani yang menasehati sekaligus memotivasinya untuk lebih giat dalam mengajar, menyempaikan ilmu kepada anak-anak dipesantren. Serta menurut Enjang Adi, ia berkata: beliau pernah menegur dikarenakan terlambat saat ada jadwal mengajar dan saat itu juga beliau mengingatkannya untuk tidak telat sekaligus kepada semua staf pengajar (Wawancara dengan staf pengajar, pada tanggal 16 Juli 2019). Dari uraian diatas dapat dipahami bahwa peranan beliau sebagai leader dibuktikan dengan memotivasi dan mengingatkan staf pengajar dalam proses mengajar. Oleh sebab itu, staf pengajar tentunya akan termotivasi, tergugah dalam proses mengajar dan kinerjanya juga akan meningkat.

Peran sebagai liaison, dalam peran ini seorang pemimpin harus memelihara jaringan kontak dengan pihak luar yang memberi dukungan dan informasi. Bedasarkan hasil wawancara dengan Ikhsanudin, ia mengatakan: beliau melakukan peranan ini dengan menjaga komunikasi dengan teman sejawatnya karena pada saat berdirinya pesantren ini ada bantuan dana dari temannya tersebut, ini membuktikan bahwa beliau menjaga komunikasi dengan pihak luar khususnya teman sejawatnya (Wawancara dengan staf pengajar, pada tanggal 16 Juli 2019).

Dari hasil wawancara diatas dapat disimpulkan bahwa beliau telah melakukan peranan sebagai liaison dimana memelihara jaringan komunikasi dengan pihak luar. Sehingga beliau mendapat bantuan dana dalam pendirian serta keperluan fasilitas bagi pesantren, dengan demikian jika fasilitas di pesantren semakin lengkap maka semakin mendukung proses pembelajaran dan kinerja staf pengajar pun akan terbantu dan meningkat. Dengan demikian dari uraian hasil wawancara diatas membuktikan bahwa peran kepemimpinan $\mathrm{H}$. Ahmad Jayani dalam interpersonal role sebagai figurbead, leader dan liaison telah dilakukan dan itu akan membantu dalam peningkatan kinerja staf pengajar.

\section{Peran Kepemimpinan H. Ahmad Jayani dalam Informational Role (Peran Sumber Informasi)}

Peranan ini menjelaskan dimana seorang pemimpin menjadi pusat informasi bagi organisasi. Sesuai dengan teori Henry Mintzberg (1973) dimana ada dua peran seorang pemimpin dalam peranannya sebagi sumber informasi. Pertama, peran monitor dan desseminator. Seorang pemimpin harus bisa memonitor atau menerima informasi yang sangat beraneka baik dari dalam atau luar organisasi, selain itu seorang pemimpin juga menjadi pusat saraf informasi bagi organisasi. 
Dengan kata lain, seorang pemimpin harus bisa mencari informasi-informasi yang akan sangat mendukung dalam perkembangan kegiatan organisasi dan juga perkembangan kinerja bawahan (Badeni, 2014: 6).

Setelah menerima informasi yang didapat seorang pemimpin harus melanjutkan peranannya sebagai desseminator yaitu meneruskan informasi penting yang didapat baik dari luar maupun dalam organisasi kepada para anggota organisasinya. Hal ini tentunya harus dilakukan oleh setiap pemimpin guna mengembangkan kegiatan keorganisasian. Baik mencari informasi dari luar atau pun dari bawahan keduanya merupakan suatu hal yang penting untuk kemajuan organisasi. Sebagai pusat informasi, pemimpin dapat memberikan jaminan atas keputusan yang terbaik, yang mencerminkan pengetahuan yang terbaru dari nilai-nilai organisasi (Prayogi: 2016).

Kedua, seorang pemimpin harus bisa menjadi juru bicara atau spokesperson. Dalam peranan ini seorang pemimpin bertanggung jawab atas pengetahuan informasi keorganisasian kepada pihak luar, tertutama pihak-pihak yang terlibat dengan organisasi tersebut. Seperti seorang kepala sekolah yang menyampaikan informasi sekolahnya mengenai pembiayaan kepada orang tua murid, karena hal demikian juga akan membantu berjalannya kegiatan organisasi. Pada intinya seorang pemimpin harus bertanggung jawab dalam menyampaikan informasiinformasi keorganisasian bilamana suatu waktu ada informasi yang perlu disampaikan kepada pihak luar.

Peranan pemimpin sebagai spokes person ini sangatlah penting untuk dilakukan, karena bilamana ada suatu informasi organisasi yang perlu disampaikan kepada pihak luar tetapi tidak tersampaikan hal ini tentunya akan menjadi pengahambat bagi keberlangsungan dan berjalannya segala aktivitas dan kegiatan yang berkaitan dengan keorganisasian. Dan sesuai dengan judul penelitian, tentunya pemimpin pondok pesantren Ibnu Rusyd ini harus bisa menjaga jaringan komunikasi dengan pihak luar terutama pesantren-pesantren, karena denan adanya jaringan kontak tersebut akan menambah informasiinformasi pendukung dalam hal pengembanan kegiatan mengajar. Selain itu, disamping kita mendapatakn informasi pendukung untuk diterapkan pada pesantren yang beliau pimpin, beliau juga bisa menyampaikan informasi perekembanan dalam sistem mengajar di pesantren yang beliau pimpin kepada pihak luar atau pesantren-pesantren lain.

Menjaga silaturrohim dengan pihak luar akan menambah informasiinformasi yang yang mungkin akan sangat mendukung terhadap kegiatan pesantren. Oleh karena itu, silaturrohim merupakan cara yang baik untuk menjalin hubungan dengan pihak luar. Menjalin silaturrohim antar organisasi atau lembaga urusan umat untuk menyamakan visi dan missi kebersamaan dalam amar ma'ruf nahi munkar, dalam sebuah agenda berupa pengajian, tabligh akbar atau acara PHBI, Perayaan Hari Besar Islam (Alkhairy, 2017). 
D. Marathon, D. Kuswana, Yuliani.

Keberhasilan melakukan komunikasi dengan seseorang, tidak hanya dibutuhkan pesan yang verbal tetapi juga non verbal yang berupa sikap dan tingkah laku, terlebih ketika antara komunikator dan komunikan memiliki latar belakang kebudayaan yang berbeda. Maka yang terpenting dalam melakukan komunikasi terhadap orang yang memiliki budaya yang berbeda adalah menggunakan pesan non verbal disamping pesan verbal (Anas \& Adinugraha, 2017).

Peran sebagai monitor and desseminator, dalam peranan ini seorang pemimpin harus memonitor atau menerima informasi yang beragam dan juga sebagai pusat informasi baik dari luar maupun dari dalam organisasi. Dan kemudian desseminator atau meneruskan informasi yang diterima kepada staf pengajar. Berdasarkan hasil wawancara dengan Iim Rohimah, ia mengatakan: ketika didalam rapat pada hari Sabtu, 01 Juni 2019. Bapak menanyakan kepada kami selaku staf pengajar seputar informasi-informasi yang penting bagi kegiatan pengajian. Jika ada beliau langsung menyampaikan kepada kami untuk melakukan informasi-informasi penting tersebut yang meningkatkan atau menambah kegiatan-kegiatan pengajian (Wawancara dengan staf pengajar, pada tanggal 16 Juli 2019).

Hasil wawancara tersebut dapat dilihat adanya upaya menstimulus atau merangsang informasi-informasi yang penting serta mendukung kegiatan pembelajaran dari para staf pengajarnya. Dengan kata lain disini akan terjadi proses memonitor atau menerima informasi dari bawahan. Dalam hal tersebut seorang pemimpin berparan sebagai monitor dan desseminator dimana menerima dan menyampaikan informasi dari bawahan untuk bawahan karena proses memonitornya dari para bawahannya dan juga desseminator untuk bawahannya juga. Sesuia dengan hasil wawancara tersebut berarti beliau melakukan proses menerima dan menyampaikan dari dalam organisasi yaitu dari bawahannya.

Menurut Nunung Aisah mengatakan: Peranan beliau dalam mencari informasi terkait kegiatan pembelajaran dari luar tentunya sudah dilakukan, karena saat diadakan rapat beliau pernah menyampaikan suatu informasi dari orang tua santri dimana mereka menginginkan peningkatan pembelajaran atau pengembangan bahasa (Wawancara pada Selasa tanggal 16 Juli 2019). Hasil wawancara ini menjelaskan bahwa adanya suatu peranan kepemimpinan dimana menyaring informasi dari luar yaitu orang tua santri dan menyampaikan informasi tersebut kepada staf pengajarnya. sesuai dengan hasil wawancara tersebut beliau telah menerima informasi dari pihak luar yaitu orang tua santri untuk kemudian menyampaikannya kembali kepada staf pengajarnya.

Sesuai dengan hasil wawancara diatas dapat disimpulkan bahwa peran kepemimpinan H. Ahmad Jayani sebagai monitor dan desseminator telah dilakukan, dibuktikan dengan cara beliau menstimulus informasi dari staf pengajarnya (dalam organisasi), serta memonitor dan mendesseninator informasi dari orang 
tua santri (luar organisasi) untuk kemudian disampaikan kepada staf pengajarnya mengenai pengembangan bahasa. Dengan demikian peran kepemimpinan tersebut akan membantu serta meningkatkan kinerja staf pengajar.

Peran sebagai spokesperson, dimana dalam peranan ini seorang pemimpin menjadi juru bicara atau menyampaikan informasi organisasi kepada pihak luar, karena hal tersebut akan sangat mendukung berjalannya kegiatan organisasi. Berelson dan Steiner (dalam Chandra, 1996: 3), menyatakan komunikasi sebagai proses penyampaian informasi, emosi, keterampilan, dengan menggunakan simbol, kata, gambar, angka, dan sebagainya. Dan, menurut Hovland, adalah upaya yang sistematis untuk merumuskan secara tegar asas-asas penyampaian informasi serta pembentukan pendapat dan sikap, bahkan secara khusus "communication is the process to modify the behavior of other individuals" (Wahyudin, (2014).

Hasil wawancara dengan Huda Saeed, ia mengatakan bahwa pada rapat hari rabu, 05 Juni 2019, beliau menyampaikan informasi kepesantrenan mengenai, perencanaan, kebijakan, kegiatan serta pembiayaan pesantren kepada orang tua santri (Wawancara dengan staf pengajar pada Selasa tanggal 16 Juli 2019). Dengan demikian seusai wawancara tersebut dapat dipahami seorang pemimpin melaksanakan peranannya sebagai spokesperson atau juru bicara yaitu beliau menyampaikan informasi-informasi yang perlu untuk disampaikan kepada pihak luar yaitu orang tua santri. Karena dengan hal tersebut akan sangat membantu berjalannya kegiatan kepesantrenan dalam mendidik santri-santri sesuai dengan harapan orang tuanya serta para orang tua santri pun akan sangat berperan loyal dan terbuka terhadap keperluan pesantren bilamana mereka sudah paham betul mengenai informasi-informasi yang disampaikan. Sehingga dengan adanya hal tersebut akan berdampak pada berjalannya kegiatan kepesantrenan.

Menurut Nurhaeti mengatakan: ketika akan diadakan rapat dengan orang tua santri, beliau selalu menyampaikan informasi tersebut sebelumnya kepada orang tua santri (Wawancara dengan staf pengajar pada Selasa tanggal 16 Juli 2019). Dari wawancara ini terlihat peranan sebagai juru bicara dimana menyampaikan suatu informasi bahwa akan diadakannya rapat bersama orang tua santri, dengan kata lain dalam hal ini juga beliau telah melakukan peranannya sebagai spokes person dalam menyampaikan informasi kepada pihak luar. Wawancara tersebut merupakan satu contoh dari sekian banyak peranan seorang pemimpin sebagai juru bicara bagi organisasi. Jadi pada intinya peranan ini memang sangat penting untuk dilakukan seorang pemimpin kareana hal ini merupakan suatu faktor yang sangat mendukung dalam kelancaran berjalannya kegiatan pesantren sesuai perencanaan yang telah ditentukan sebelumnya.

Hasil uraian di atas dapat disimpulkan bahwa peran kepemimpinan $\mathrm{H}$. Ahmad Jayani sebagai spokesperson atau juru bicara telah dilaksanakan. Dibuktikan dengan menjadi juru bicara dalam penyampaian informasi seputar pesantren 
D. Marathon, D. Kuswana, Yuliani.

kepada orang tua santri (pihak luar) dan juga menjadi juru bicara saat penyampaian informasi akan diadakan rapat bersama dengan orang tua santri. Hasil wawancara tersebut merupa satu dari sekian banyak contoh peran kepemimpinan sebagai spokes person dimana menjadi juru bicara bagi pesantren. Karena untuk informasi yang disampaikan kepada pihak luar tentunya suatu organisasi dengan organisasi lain dalam hal meyampaikan informasi-informasi pastinya akan berbede-beda disesuaikan dengan keperluan dan kepentingan yang dibutuhkan oleh organisasi. Dengan kata lain, ketika informasi kepesantrenan mengenai perencanaan, kebijakan, kegiatan serta pembiayaan telah disampaikan kepada orang tua sentri, terhusus dalam hal pembiayaan yang akan sangat membantu dalam pengembangan fasilitas pembelajaran yang otomatis akan membantu dan meningkatkan kinerja staf pengajar dalam mengajar.

\section{Peran Kepemimpinan H. Ahmad Jayani dalam Decision Making (Peran Pembuatan Keputusan)}

Pengambilan keputusan merupakan unsur yang penting dalam kehidupan ini, termasuk didalamnya kehidupan dalam berorganisasi (Badeni, 2014: 50). Adapun bagian dari peran decision making sesuai dengan teori Henry Mintzberg (1973) yaitu; Pertama, peran kepemimpinan sebagai enterpreneur, dimana seorang pemimpin harus mencari kesempatan didalam organisasi serta lingkungan dan memprakarsai proyek-proyek yang menimbulkan perubahan. Dengan kata lain seorang pemimpin harus mempunyai ide-ide serta inovasi baru yang berguna, mendukung serta meningkatkan perkembangan kegiatan didalam organisasi yang dipimpinnya (Badeni, 2014: 7).

Selain itu seorang pemimpin juga harus bisa menstimulus bawahannya untuk memberikan aspirasinya mengenai inovasi baru yang membantu perkembangan kegiatan organisasi. Mereka tidak melakukan kritik di muka umum terhadap bawahannya. Gagasan-gagasan baru dan solusi kreatif atas masalah diperoleh dari bawahan yang dilibatkan dalam proses penyelesaian masalah. Dengan cara ini, para bawahan memiliki keberanian untuk mencoba pendekatan-pendekatan baru (Allolangi, 2014).

Kedua, peran kepemimpinan sebagai disturbance handler, dimana seorang pemimpin harus berperan bertanggungjawab atas tindakan korektif bila organisasi menghadapi gangguan mendadak dan penting yang akan menghambat berjalannya kegiatan pada organisasi. Dengan demikian apabila ada kendala yang timbul yang mengancam berjalannya kegiatan keorganisasian seorang pemimpin harus melakukan peranannya sebagai distrurbance handler untuk terjun langsung mengatasi kendala tersebut guna melancarkan kegiatan organisasi supaya berjalan dengan baik sesuai yang diharapkan.

Ketiga, peran kepemimpinan sebagai resource allocator, dalam peranan ini seorang pemimpin harus mengambil atau menyetujui keputusan organisasi yang 
penting seperti penjadwalan, permintaan otorisasi, penganggaran dan pemrograman kerja bawahan. Selain itu, dalam peranan ini seorang pemimpin juga harus bisa menempatkan sumber daya manusia pada posisi yang tepat sesuai dengan kompetensi yang dimiliki masing-masing orang karena itu akan sangat membantu dalam pelaksanaan tugas dan hasil kerja pun tentunya akan sesuai dengan yang diinginkan.

Keempat, peran kepemimpinan sebagai negotiator, dimana seorang pemimpin bertanggung jawab mewakili organisasi pada perundingan, terutama saat perundingan dengan pihak luar organisasi untuk mencari hal-hal baru untuk perkembangan organisasi. Disamping bernegosiasi dengan pihak luar, seorang pemimpin juga harus bisa menjadi perunding dengan bawahannya bilamana adanya informasi-informasi yang perlu disampaikan kepada bawahan atau sebaliknya dari bawahan kepada pemimpinnya. Keputusan-keputusan yang strategis akan lebih mudah diambil secara terpadu dengan adanya satu orang yang dapat melakukan control atas semuanya. Analisa bahwa strategi itu merupakan opsi yang muncul terkait apa kekuatan dan kelemahan organisasi, apa peluang dan tantangan, peluang perbaikan dan assessment data, adapun salman memiliki kelebihan yaitu mempunyai akses kepakaran yang cukup tinggi dan jaringan organisasi yang cukup baik (Prayogi, 2016).

Peran sebagai enterpreneur, dimana dalam peranan ini seorang pemimpin harus mampu memunculkan ide-ide serta inovasi yang baru bagi pesantren khususnya dalam kegiatan pembelajaran. Paling tidak ada empat fungsi dasar fungsi fasilitatif dari seorang fasilitator, yaitu: Pertama, Stimuli emosional, menggambarkan prilaku fasilitator yang bergairah, ekspresif yang berpribadi dan penuh emosi. Fungsi ini dilaksanakan ditengah para peserta. Kedua, Kepedulian, adalah isu yang terpisah dari keahlian teknis, ia dibuktikan dengan pengembangan khusus, yang hangat dengan anggota kelompok. Ketiga, Atribut yang bermanfaat. Ia dicapai dengan pesiapan penjelasan perilaku perubahan kognitif dan definisi kerangka kerja untuk berubah. Hal ini memberikan manfaat untuk pengalaman. Keempat, Fungsi ekskutif, yaitu pendekatan (Alkhairy, 2017).

Berdasarkan hasil wawancara dengan Ina Rostina, ia mengatakan: beliau selalu memotivasi staf pengajar untuk membuat inovasi-inovasi baru dalam kegiatan pesantren. Bapak juga selalu mengeluarkan ide-idenya yang dianggap penting untuk kegiatan pesantren. Seperti setiap hari minggu di minggu keempat diadakannya bakti sosial, cinta lingkungan anak-anak pesantren terhadap lingkungan dan juga diadakannya kegiatan lapangan bagi anak-anak pesantren sebagai penghilang rasa jenuh bagi mereka dan terakhir kegiatan ini dilaksanakan yaitu pada tanggal 30 Juni 2019 (Wawancara dengan staf pengajar pada tanggal 17 Juli 2019).

Hasil wawancara diatas penulis simpulkan, dimana terdapat dua point penting. Pertama ada upaya dalam menstimulus atau merangsang inovasi-inovasi 
D. Marathon, D. Kuswana, Yuliani.

baru dari para staf pengajar. Kedua penyampaian ide baru dari pemimpin kepada staf pengajar dalam hal kegiatan lapangan. Dengan kata lain sesuai dengan hasil wawancara diatas bahwa peran kepemimpinan H. Ahmad Jayani dalam enteurpreneur telah dilakukan dibuktikan dengan ide barunya dalam mengadakan kegiatan lapangan bagi para santri, dengan otomatis ini akan membantu peningkatan kinerja staf pengajar.

Peran sebagai disturbance handler, dalam peranan ini seorang pemimpin bertanggungjawab atas tindakan korektif apabila organisasi menghadapi gangguan mendadak dan penting, terhusus dalam kegiatan pembelajaran. Bedasarkan hasil wawancara dengan Taufik Hidayat, ia mengatakan: ketika diadakan rapat, beliau selalu bertanya kepada masing-masing staf pengajar bila mana ada kendala atau masalah-masalah yang dihadapi, yang dapat berdampak terhadap kegiatan belajar mengajar atau pun bagi pesantren. Dan kemudian dicarilah solusi untuk mengatasi masalah-masalah tersebut (Wawancara dengan staf pengajar pada tanggal 17 Juli 2019). Dari wawancara di atas dapat disimpulkan bahwa adanya upaya mengatasi kendala dengan pertama-tama menanyakan terlebih dahulu kepada staf pengajar bilamana terjadi kendala dalam kegiatan pembelajaran untuk dicarikan solusinya.

Menurut Jajang Wahyudin mengatakan: dulu pernah ada kendala yang berdampak pada kegiatan pengajian, yaitu adanya kerusakan pada fasilitas papan tulis dan pasti perlu adanya dana untuk membelikan yang baru. Saya beritahukan kepada Bapak kendala tersebut, kemudian Bapak membelikan fasilitas papan tulis setelahnya (Wawancara dengan staf pengajar pada tanggal 17 Juli 2019). Dari hasil wawancara di atas, terdapat peranan langsung dalam mengatasi permasalahan berupa rusaknya fasilitas pembelajaran yaitu papan tulis dan kemudian beliau membeli lagi yang baru.

Dengan demikian dilihat dari hasil wawancara di atas, peran kepemimpinan H. Ahmad Jayani dalam disturbance bandler telah dilakukan, dibuktikan dengan pertama adanya upaya mencegah atau mengatasi kendala kegiatan pembelajaran dengan menanyakannya kepada masing-masing staf pengajar, kedua adanya tindakan langsung setelah mengetahui adanya kendala berupa kerusakan pada fasilitas papan tulis sehingga dibelikan yang baru. Dan hal tersebut akan sangat membantu terhadap kelancaran kegiatan pembelajaran serta meningkatkan kinerja staf pengajar sekaligus mempermudah dalam kegia tan pembelajaran.

Peran sebagai resource allocation, dalam peranan ini seorang pemimpin harus mengambil atau menyetujui keputusan organisasi yang penting dan memiliki kewenangan dalam pendayagunaan sumberdaya manusia. Berdasarkan hasil wawancara dengan Saeful Nustika, ia mengatakan: "Menurut saya beliau sangat bertanggung jawab dalam memutuskan, seperti pembagian tempat pada kepengurusan di organisasi pesantren. Beliau selalu bermusyawarah untuk 
mufakat dalam pengambilan keputusan. Penempatan tersebut tidak asal menempatkan tetapi juga disesuaikan dengan kompetensi atau keahlian dari masing-masing" (Wawancara pada tanggal tanggal 17 Juli 2019). Hasil wawancara di atas, dijelaskan bahwa peranan kepemimpinan dalam resource allocation atau penentuan sumber daya dibuktikan dengan penentuan sumber daya pada kepengurusan di pesantren, karena penentuan sumber daya tersebut pasti melihat dulu bagaimana kompetensi yang dimiliki.

Menurut Ayi Ida Mulyani mengatakan: "Dari awal sebenarnya peran ini sudah dilakukan oleh beliau. Saat pembagian memegang materi-materi pelajaran pengajian kepada kami. Itu juga hasil pertimbangan beliau dalam pendayagunaan sumber daya manusia khususnya staf pengajar. Seperti pengajar ini memegang pelajaran tajwid, pengajar ini mengajar kitab-kitab dan lain-lain" (Wawancara dengan staf pengajar pada tanggal 17 Juli 2019). Hasil wawancara di atas dijelaskan peran pengalokasian sumber daya dengan penentuan atau pembagian materi pembelajaran kepada staf pengajar disesuaikan dengan kompetensi dan kemampuan dari masing-masing staf pengajar.

Dengan demikian, melihat uraian di atas dapat disimpulkan bahwa peran kepemimpinan $\mathrm{H}$, Ahmad Jayani sebagai reurce allocation atau keputusan dalam menetapkan sumber daya telah dilkaukan. Dibuktikan dengan pertama, penetapan sumber daya pada kepengurusan organisasi pesantren yang disesuaikan dengan kompetensi dan kemampuan yang dimiliki masing-masing pengurus. Kedua, penetapan sumberdaya dalam hal memegang materi-materi pembelajaran kepada staf pengajar yang tentunya disesuaikan dengan kompetensi dan kemampuan yang dimiliki oleh masing-masing staf pengajar. Oleh karena itu, ketika penetapan seumber daya dalam pemegang mataeri pembelajaran sudah disesuaikan dengan kompetensi dan kemampuan yang dimiliki masing-masing staf pengajar, hal ini akan membantu meningkatkan kinerja staf pengajar dalam kegiatan pembelajaran dikarenakan mereka telah berkompeten sesuai dengan yang telah diputuskan oleh pemimpin.

Peran sebagai negotiator, dalam peran ini seorang pemimpin bertanggungjawab dalam mewakili organisasi dalam perundingan baik dengan pihak luar maupun dalam organisasi. Berdasarkan hasil wawancara dengan Entus Nurdin Ahmad, ia mengatakan: Saat rapat dengan guru-guru ngaji, beliau pernah memberi hal baru terkait kegiatan pengajian seperti pengembangan bahasa arab melalui mufrodat dan itu menurut saya hasil beliau menjalin hubungan dan bernegosiasi dengan pesantren lain sehingga mandafatkan informasi-informasi yang bermanfaat bagi kegiatan pesantren khususnya dipengajian (Wawancara dengan staf pengajar pada tanggal 17 Juli 2019). Dari hasil wawancara tersebut, dijelaskan bahwa adanya hubungan negosiasi antara H.Ahmad Jayani dengan pihak luar atau pesantren lain yang mendukung kegiatan pembelajaran bagi staf pengajar, dibuktikan dengan beliau menyampaikan idenya dalam pengembangan 
D. Marathon, D. Kuswana, Yuliani.

bahasa arab melalui mufrodat.

Menurut Eneng Kurniasih mengatakan: "Setiap rapat dengan kami, beliau selalu bernegosiasi dengan kami mengenai kinerja kami dalam mengajar" (Wawancara pada tanggal tanggal 17 Juli 2019). Dari hasil wawancara tersebut, dapat dipahami bahwa peran kepemimpinan dalam bernegosiasi dilakukan dengan staf pengajar mengenai kinerja dalam mengajar.

Berdasarkan hasil uraian wawancara di atas membuktikan bahwa peranan kepemimpinan H. Ahmad Jayani sebagai negisiator dibuktikan dengan bernegosiasi dengan pihak luar yaitu dengan pesantren lain sehingga beliau menyampaikan informasi baru mengenai pengembangan bahasa arab dengan mufrodat. Bernegosiasi dengan staf pengajarnya sendiri mengenai kinerja staf pengajar, dengan kata lain ini merupakan proses evaluasi terhadap staf pengajar dalam melakukan kegiatan mengajar dan tentunya ini akan meningkatkan kinerja staf pengajar.

\section{PENUTUP}

Berdasarkan hasil penelitian yang dilakukan di Pondok Pesantren Ibnu Rusyd Cinunuk mengenai Peran Kepemimpinan H. Ahmad Jayani dalam Meningkatkan Kinerja Staf Pengajar maka dapat disimpulkan: Pertama, peran interpersonal role $\mathrm{H}$. Ahmad Jayani telah dilakukan peranannya baik secara langsung maupun tidak terhadap staf pengajarnya. Perannannya sebagai figurhead selalu memberi contoh untuk selalu rajin dalam segala aktivitas kegiatan pesantren. Seperti selalu mengajak untuk persiapan shalat kepada staf pengajarnya. Kedua, peranannya sebagai leader juga terlihat dalam memotivasi dan mengarahkan staf pengajar. Seperti memotivasi staf pengajar untuk ikhlas dalam mengajarkan ilmu kepada anak-anak santri. Ketiga, peranannya sebagai liaison terbukti dengan adanya hubungan komunikasi baik dengan pihak luar baik organisasi maupun individu. Seperti menjaga hubungan komunikasi dengan teman sejawatnya. Dan peranan tersebut tentunya akan meningkatkan kinerja staf pengajarnya.

Peran informasional role juga telah dikaukan oleh beliau terhadap staf pengajarnya. Pertama, peranannya sebagai monitor and dessimilator dimana beliau telah melakukan penyaringan terhadap informasi-informasi dari luar dan disampaikan kepada staf pengajarnya. Seperti menghimpun informasi dari staf pengajar yang berguna untuk kegiatan pesantren. Kedua, peranannya sebagai spoke person dimana telah menyampaikan berbagai informasi pesantren kepada pihak luar. Seperti menginformasikan tentang perencanaan, kebijakan, kegiatan dan pembiayaan pesantren kepada orang tua santri. Hal ini akan mempengaruhi peningkatan kinerja staf pengajar di Pondok Pesantren Ibnu Rusyd.

Peran decision making peranan ini juga telah dilakukan oleh H. Ahmad Jayani terhadap staf pengajar di pondok pesantren Ibnu Rusyd. Pertama, peran 
sebagai enterpreneur dimana beliau telah mengidentifikasi ide baru bagi pesantren. Seperti diadakannya kegiatan lapangan bagi anak-anak pesantren. Kedua, peran sebagai distrubance bendler dimana ketika ada masalah yang timbul di pesantren beliau langsung turun tangan mengatasinya. Seperti adanya masalah kekurangan fasilitas mengajar berupa papan tulis dan beliau langsung membelinya. Ketiga, peran sebagai resorurce allocation juga telah dibuktikan dengan adanya pengambilan keputusan dalam menempatkan staf pengajar sesuai dengan materi yang dikuasai sesuai keahlian staf pengajar. Keempat, peran sebagai negosiator juga telah dilakukan dimana menjadi penghubung lembaga pesantren dengan pesantren lain apabila dibutuhkan informasi yang bermanfaat bagi pesantren. Seperti adanya pengembangan pengajaran bahasa arab dengan mufrodat yang merupakan hasil negosiasi atau hubungan dengan pesantren lain. Peran ini juga dalam upaya meningkatkan kinerja staf pengajar di Pondok Pesantren Ibnu Rusyd.

Berdasarkan hasil kesimpulan di atas, maka peneliti merekomendasikan beberapa hal untuk kedepannya: (1) Peran H. Ahmad Jayani dalam meningkatkan kinerja staf pengajar harus selalu melakukan koordinasi terhadap staf pengajar. Sebagai upaya mengurangi bahkan menghilangkan kebiasaan staf pengajar yang kurang disiplin terhadap waktu, seperti kedatangan saat jam mengajar. (2) Adanya konfirmasi staf peng ajar jika memang tidak bisa hadir untuk mengajar. Dan juga untuk staf pengajar yang masih kurang disiplin waktu dan tidak ada koordinasi kepada pimpinan harus meninggalkan kebiasaan tersebut dan lebih menghormati waktu serta mengkonfirmasi kepada pimpinan, jika ada hal penting yang bentrok dengan kegiatan pengajaran di Pondok Pesantren Ibnu Rusyd. Dan semua staf pengajar diharuskan untuk selalu jujur, amanah dalam tugas, akan tetapi tidak hanya staf pengajar, pemimpin pun harus bersikap jujur, karena itu yang nanti akan menimbulkan fokus dalam memperhatikan dan meningkatkan kinerja staf pengajar.

\section{DAFTAR PUSTAKA}

Alkhairy, G. (2017). Peran Pimpinan Pondok Pesantren Dalam Meningkatkan Kualitas Dakwah Santri. Anida (Aktualisasi Nuansa Ilmu Dakwah).https://journal.uinsgd.ac.id/index.php/anida/article/view/5053 $\angle 2838$

Allolangi, Y. (2014). Kepemimpinan Transformasional sebagai Kepemimpinan Dakwah. Ilmu Dakwah: Academic Journal for Homiletic Studies, 6(1), 151-169.

Anas, A., \& Adinugraha, H. (2017). Dakwah Nabi Mubammad terhadap Masyarakat Madinah Perspektif Komunikasi Antarbudaya. Ilmu Dakwah: Academic Journal for Homiletic Studies, 11(1), 53-72.

Anoki, H. (2010). Pengaruh Kompensasi Terhadap Kinerja Karyawan PT. Slamet Langgeng Purbalingga Dengan Motivasi Kerja Sebagai V ariabel Intervening.

Arifin, S. (2004). Leadership Ilmu dan Seni Kepemimpinan. Jakarta: Mitra Wacana 
D. Marathon, D. Kuswana, Yuliani.

Media.

Badeni, M.A (2014). Kepemimpinan Dan Perilaku Organisasi. Bandung: Alfabeta

Baidan, N. dan Aziz, E. (2014). Etika Islam dalam Berbisnis. Yogyakarta: Pustaka Pelajar

Faisal, Y. A. (1995) Reorientasi Pendidikan Islam. Jakarta: Gema Insani Press.

Fardi, A. (2014). Peran Kepemimpinan Ketua DKM dalam Mengatasi Masalah Kinerja Staf.

Farihah, I., \& Ismanto, I. (2018). Dakwah Kiai Pesisiran: Aktivitas Dakwah Para Kiai di Kabupaten Lamongan. Ilmu Dakwah: Academic Journal for Homiletic Studies, 12(1), 46-60.

Friedman, M. 1998. Keperawatan Keluarga Teori dan Praktek. Edisi 3. Jakarta: Salemba Medika.

Hasibuan, M. (2006). Manajemen Dasar Pengertian dan Masalah. Edisi Revisi, Jakarta: Bumi Aksara.

Horton, P. B., dan Hunt, C. L. (1999). Sosiologi. Erlangga. Jakarta.

Marihot, M. (2001). Manajemen Sumber Daya Manusia. Yogyakarta: BPFE.

Marlina, E. (2014). Motivasi Berpuasa Ramadhan dan Moralitas Remaja. Ilmu Dakwah: Academic Journal for Homiletic Studies, 6(2), 249-265.

Moeheriono, (2012). Pengukuran Kinerja Berbasis Kompetensi. Jakarta: Raja Grafindo Persada.

Prayogi, A. (2016). Peran Kepemimpinan Yayasan Pembina Masjid dalam Proses Kaderisasi Mahasiswa. Tadbir: Jurnal Manajemen Dakwah https://jurnal.fdk.uinsgd.ac.id/index.php/tadbir/article/view/141

Raharjo, D. (1995). Pesantren dan Pembaharuan, Jakarta: LP3ES

Sa'diyah, D. (2015). "Isu Perempuan" (Dakwah dan Kepemimpinan Perempuan dalam Kesetaraan Gender). Ilmu Dakwah: Academic Journal for Homiletic Studies, 4(12), 305-334.

Soekanto, S. (2012). Sosiologi suatu pengantar. Jakarta: Rajawali Pers

Suhartini, T. (2015). Peranan Pemimpin dalam Meningkatkan Kualitas Sumber Daya Manusia.

Suradinata, E. (1997). Pemimpin Dan Kepemimpinan Pemerintahan. Jakarta: Gramedia Pustaka Utama

Wahyudi, E. (2018). Peran Pemimpin dalam Meningkatkean Kinerja Pegawai. Skripsi.

Wahyudin, A. (2014). Episteme Dakwatologi Komunikasi: Menakar Komunikasi Islam dalam Epsitemologi Triangular Relationship. Ilmu Dakwah: Academic Journal for Homiletic Studies, 6(2), 207-225.

Yaqub, H. (1984). Menuju Keberhasilan Manajemen dan Kepemimpinan. CV Diponegoro. 